KS. BRONISŁAW CZAPLICKI - PETERSBURG

\title{
DOKUMENTY ROSYJSKIE Z POCZATKU XX WIEKU NA TEMAT JASNEJ GÓRY
}

Moje opracowanie dokumentów archiwalnych dotyczy zasadniczo okresu przed I wojną światową. Czasami jednak należało odnieść się do informacji i dokumentacji z okresu wcześniejszego, gdyż bez takich informacji owoce niniejszych badań byłyby niezrozumiałe. Moim zamiarem jest nie tyle odtworzenie wydarzeń na Jasnej Górze w oznaczonym czasie, ponieważ są one skądinąd znane. Pragnę, korzystając z dokumentów rosyjskich, odnotować te postanowienia i działania ludzkie, które zadecydowały o przetrwaniu klasztoru paulinów w okresie trudnym z powodu zagrożeń zewnętrznych i wewnętrznych doświadczeń.

Jasną Górą interesowały się rosyjskie władze administracyjne i policyjne: powiatowe w Częstochowie, gubernialne w Piotrkowie Trybunalskim, krajowe (urzędy generał-gubernatora warszawskiego) i centralne (ministerstwa rządu rosyjskiego) oraz sam imperator. Ponieważ wszystkie najważniejsze decyzje, dotyczące Kościoła katolickiego, w tym także Jasnej Góry, zapadały w należącym do ministerstwa spraw wewnętrznych Departamencie Spraw Duchownych Wyznań Obcych (Departament Duhovnyh Del Inostrannyh Ispovedanij - DDDII), tam należy szukać ich dokumentacji. Zachowały się one w Rosyjskim Państwowym Archiwum Historycznym w Petersburgu (Rossijskij Gosudarstvennyj Istoričeskij Arhiv - RGIA).

Należy jednak zaznaczyć, że tematy katolickie w RGIA mogą znajdować się nie tylko w zespole 821, zawierającym materiały DDDII. Sporo dokumentacji znajduje się także w zespole Kolegium Rzymskokatolickiego (822) czy Kancelarii metropolity kościołów rzymskokatolickich w Rosji (826). Znajdują się one także w zbiorach ministerstw, np. Finansów, Rolnictwa, Dworu cesarskiego, Oświaty itd. oraz takich urzędów, jak Rada Państwa czy Senat, a nawet Synod ${ }^{1}$.

Ks. Bronisław Czaplicki - dr historii, wykładowca Wyższego Seminarium Duchownego w Petersburgu.

${ }^{1}$ Por. dane zawarte w informatorze: Historia Kościoła Rzymskokatolickiego w Imperium Rosyjskim (XVIII-XX w.) wdokumentach Rosyjskiego Państwowego Archiwum Historycznego, Sankt Petersburg - Warszawa 1999, opr. pod red. K. Pożarskiego. 
Pewna ilość dokumentów, pochodzących z różnych struktur administracyjnych Nadwiślańskiego Kraju, znajduje się w moskiewskim Archiwum Państwowym Federacji Rosyjskiej (Gossudarstvennyj Arhiv Rossijskoj Federacii - GARF)².

Niektóre dokumenty rosyjskie, pochodzące z urzędów miejscowych, znajdują się w Polsce. Zasadnicza część dokumentów, wypracowanych w urzędach guberni piotrkowskiej, do której należała Częstochowa, przechowywana jest w Archiwum Państwowym w Łodzi (APŁ). Próby zorientowania się, czy jeszcze w innych polskich archiwach nie ma dokumentów rosyjskich o Jasnej Górze, na podstawie inwentarzy opublikowanych w internecie lub przez prywatne kontakty, nie dały rezultatu. Pewne dokumenty rosyjskie, na przykład dotyczące poszczególnych zakonników, znajdują się w Archiwum Jasnej Góry. Ich treść przedstawiam w oddzielnym opracowaniu ${ }^{3}$.

\section{Dokumenty z archiwów rosyjskich}

\section{Dokumenty opublikowane}

Znaczna część dokumentów, zgromadzonych w Petersburgu w Rosyjskim Państwowym Archiwum Historycznym (RGIA) w zespole (fondzie) 821 Departamentu Spraw Duchownych Wyznań Obcych, dotyczących Jasnej Góry ${ }^{4}$ została opublikowana w 18 numerze „Studia Claromontana” Należy z podziwem ocenić ogrom pracy, dokonanej przez Julię Godlewską. Praca ta polegała na skopiowaniu w RGIA wielu teczek dokumentów, dotyczących Jasnej Góry, oraz na ich przetłumaczeniu na język polski. Dokumenty te zostały przywiezione do Polski w postaci mikrofilmów, rozszyfrowane i opracowane 5 .

\footnotetext{
${ }^{2}$ Opublikowane w internecie inwentarze mówią np. o posiadaniu przez GARF 95 poszytów z Kancelarii gubernatora piotrkowskiego, 108 poszytów zespołu Zarządu żandarmerii w powiecie częstochowskim i noworadomskim (Radomsko), 31 poszytów zespołu Zarządu generał-policmajstra Królestwa Polskiego, 443 poszytów zespołu Kancelarii warszawskiego ober-policmajstra, 44 poszytów zespołu Piotrkowskiego sądu okręgowego itp. Znajdują się tam też materiały dotyczące działalności niektórych oddziałów Ochrany. Por. http://garf.ru/local.RI.htm

${ }^{3}$ Por. przygotowany do druku mój artykuł: „Dokumenty rosyjskie w Archiwum Jasnej Góry”.

${ }^{4}$ Por. inwentarze dokumentów, dotyczących Kościoła katolickiego, zgromadzonych w RGIA, opublikowane po rosyjsku w informatorze: Kościót katolicki warchiwach Departamentu Wyznań Obcych MSW, red. M. S. Radwan, A. R. Sokołow, t.1-5, Sankt-Petersburg 2000-2001. Opracowanie jest publikacją archiwalnych inwentarzy: 1, 2, 3, 4, 6, 10, 11, 12, 13, 125, 128, 138, 141, 142, 144, 145, 149, 150, 152 z zespołu: 821 - Departament Duhownych Del Inostrannyh Ispovedanij.

${ }^{5}$ Akta rządu carskiego, dotyczące Jasnej Góry z lat 1868-1914. Dokumenty zebrała i thumaczyła Julia Godlewska, wstępem i komentarzem opatrzył Janusz Zbudniewek ZP, w: SC 18 (1998), s. 235 382. W RGIA można znaleźć dokumenty, dotyczace Kościoła katolickiego także w innych zespołach. Jednakże w nich nie ma „dieł” (poszytów), dotyczących Jasnej Góry. Por. informacje opublikowane w następujących wydaniach: Historia Kościoła Rzymskokatolickiego w Imperium Rosyjskim (XVIIIXX w.) w dokumentach Rosyjskiego Państwowego Archiwum Historycznego, Sankt Petersburg Warszawa 1999, opr. pod red. K. Pożarskiego. Por. także: Historia Kościoła Rzymskokatolickiego $w$ Rosji i Polsce $w$ dokumentach archiwów, bibliotek i muzeów Sankt Petersburga. Zarys przewodnik. cz. 2, Sankt Petersburg - Warszawa 2000, opr. pod red. K. Pożarskiego.
} 
Zgromadzone w RGIA dokumenty są na ogół rękopisami. Są to bądź oryginały bądź kopie. Opracowane materiały to dokumenty własne DDDII oraz korespondencja docierająca do tego urzędu. Ich autorami byli pracownicy DDDII oraz innych urzędów centralnych i departamentów ministerstwa, kancelarii warszawskiego generał-gubernatora, urzędów guberni piotrkowskiej i struktur policyjnych różnego szczebla, np. częstochowskiego policmajstra. W teczkach RGIA są też zebrane wycinki prasowe, listy, prośby, donosy i inne dokumenty. W w kancelarii DDDII pozostawiano kopie wysłanych dokumentów, a oryginały trafiały do adresatów.

Trudną sprawą przy opracowaniu dokumentów jest próba rekonstrukcji nazwisk. W dokumentach podawane były one na różne sposoby: w wersji pełnej (imię, otczestwo i nazwisko), w skróconej (na przykład tylko nazwisko). Nieraz podawano nazwisko bez funkcji i tytułów lub też funkcję, lecz bez nazwiska.

Ponieważ zakony katolickie zostały przez rosyjskie władze państwowe poddane jurysdykcji biskupów, dlatego też władze żądały od biskupów niesienia odpowiedzialności za przestrzeganie prawa państwowego przez klasztory. Stąd brały się interwencje biskupów diecezji kujawsko-kaliskiej, na terenie której znajdowała się Jasna Góra, co też odzwierciedlają dokumenty.

Zbiory DDDII, przechowywane w RGIA, zawierają wiele teczek osobowych, dotyczących katolickich biskupów i kapłanów. Jednakże oprócz jednego poszytu, dotyczącego o. Bonawentury Gawełczyka ${ }^{6}$, treść którego została opublikowana w 18 numerze SC opracowana, nie ma tam innych teczek personalnych, dotyczących paulinów. Nie ma nawet personalnej teczki o. Piusa Przeździeckiego, którym władze interesowały się szczególnie ${ }^{7}$.

W wymienionym artykule opublikowano nie wszystkie dokumenty, przechowywane w RGIA, dotyczące Jasnej Góry. Poniżej charakteryzuję te poszyty, które nie były zbadane.

\section{Dokumenty nieopublikowane (przegląd)}

Dokumenty, dotyczące spraw katolickich, oprócz RGIA, znajdują się także w innych archiwach i bibliotekach Petersburga. Nie dotyczą jednak Jasnej Góry ${ }^{8}$.

${ }^{6}$ RGIA, F. 821, op. 3, d. 269 - Sviaŝennik Bonaventura Gavelčik. O skazaniu na zesłanie o. Piotrowskiego mówi jedynie sprawozdanie, składane carowi. Nie stanowi ono osobnej teczki. Por. RGIA, F. 821, op. 3, d. 17.

7 Józef (o. Pius) Przeździecki (1865-1942). Wstąpił do klasztoru na Jasnej Górze jako kapłan diecezjalny. Był zwolennikiem reform w formacji paulinów. Wspierał tajne zgromadzenia zakonne, zwłaszcza działające na niwie wychowania młodzieży i formacji inteligencji. Był w opozycji do długoletniego przeora, o. E. Rejmana. Po I wojnie światowej pełnił odpowiedzialne funkcje w zakonie paulinów. Por. O. Przeździecki Pius, w: J. S. Płatek, Dzieje paulinów XX wieku-życie i działalność, Częstochowa 2003, s. 623-644.

${ }^{8}$ Centralne Państwowe Archiwum Historyczne gromadzi zasadniczo materiały instytucji Kościoła katolickiego z Petersburga i okolic. Archiwum Rękopisów Instytutu Historii Materialnej Rosyjskiej Akademii Nauk (RAN) zawiera sporo materiałów o różnych budynkach kościelnych. 
Poniżej przedstawię pokrótce zawartość teczek: 173, 174, 175 i 176, należących do sygnatury (opisu) 128, w 821 fondzie (zespole) w RGIA oraz niektóre osobiste decyzje cara Mikołaja II, zawarte w teczkach 75 i 85 z opisu $11 \mathrm{w}$ tym samym 821 zespole (fondzie). Wszystkie te teczki dotyczą jednoznacznie losów klasztoru jasnogórskiego. Wymienione teczki z opisu 128 w całości dotyczą Jasnej Góry, chociaż niektóre dokumenty w szerszym kontekście, natomiast teczki 75 i 85 z opisu 11 zawierają różnego rodzaju dokumenty, będące sprawozdaniami, jakie minister spraw wewnętrznych periodycznie składał imperatorowi. Wśród tych sprawozdań były też dotyczące Jasnej Góry.

Wspomniana teczka nr 75 z opisu 11 zawiera decyzje Mikołaja II, które dla Jasnej Góry miały znaczenie pozytywne. Sprawę przekazał minister spraw wewnętrznych, P. Durnowo 13 IX 1900 r. Car sam przekazał na rzecz prowadzenia remontów na Jasnej Górze sumę 5 tys. rubli i 16 IX 1900 r. pozwolił na prowadzenie wśród wiernych katolików na terenie całego Królestwa Polskiego (oprócz terenów zamieszkałych przez byłych unitów) zbierania pieniędzy do wysokości 150 tys. rubli., zgodnie z propozycją księcia Imertyńskiego, generał-gubernatora warszawskiego ${ }^{9}$. Treść teczki nr 85 przedstawimy niżej.

Teczka nr 173 jest najbardziej obszerna z tych, które dotyczą Jasnej Góry. Chociaż nosi ona nazwę: „O częstochowskim klasztorze paulinów”, to zebrane w niej zostały też materiały (głównie wycinki gazet), dotyczące innych wydarzeń z życia Kościoła katolickiego. Materiały zawarte w teczce dotyczą lat 1909-1914. Zebrane wycinki pochodzą przeważnie z rosyjskich i polskich gazet, ukazujących się w różnych miejscowościach. Oprócz tego teczka zawiera obfitą korespondencję między następującymi osobami i urzędami: ministrem spraw wewnętrznych, biskupem kujawsko-kaliskim, gubernatorem piotrkowskim, kancelarią generalgubernatora warszawskiego, DDDII, władzami policyjnymi.

W swoim opracowaniu nie będę wyliczał wszystkich materiałów, znajdujących się w teczce, lecz spróbuję streścić najważniejsze dokumenty.

W 1909 r., generał-gubernator warszawski Georgij Antonowicz Skałon posłał do Częstochowy swojego wysłannika, urzędnika Wasilija Iwanowicza Tiażelniko$\mathrm{wa}^{10}$, który w jego imieniu przeprowadził w klasztorze śledztwo. Wyjechał on do

Podobnie też Filia Archiwum RAN. Wiele różnych pozycji, w tym kodeksów, pochodzących $\mathrm{z}$ różnych krajów $\mathrm{z}$ okresu od $\mathrm{X}$ do $\mathrm{XX}$ wieku posiadają takie biblioteki, jak sanktpetersburski Oddział RAN czy Oddział Rękopisów Rosyjskiej Biblioteki Narodowej. Są wśród nich fragmenty historycznych zbiorów różnych katolickich bibliotek, w tym także biblioteki Akademii Duchownej w Petersburgu. Wśród zasobów Rosyjskiej Biblioteki Narodowej znajdujemy kodeksy z różnych

klasztorów, nie tylko z terenu byłych polskich Kresów wschodnich, lecz np. z Francji. Por. Historia Kościola Rzymskokatolickiego w Rosji i Polsce wdokumentach archiwów, bibliotek i muzeów Sankt Petersburga. Zarys - przewodnik. cz. 2, Sankt Petersburg - Warszawa 2000, opr. pod red. K. Pożarskiego.

${ }^{9}$ RGIA, F. 821, op. 11, d. 75 - Vsepoddannejšie doklady ministra VD po DDDII za 1900 g., k. 35 - 35 odwr. [Zgoda Mikołaja II 16 IX 1900]

10 W. I. Tiażelnikow był początkowo pracownikiem kancelarii do spraw duchownych warszawskiego generał-gubernatora. Od 1910 r. pracował w DDDII. Przeprowadził wtedy szereg rewizji w moskiewskich, petersburskich i innych katolickich ośrodkach wychowawczych 
Częstochowy 8 sierpnia. Postanowił zbadać kulisy odsunięcia przeora Rejmana ze stanowiska oraz inne naruszenia państwowego prawodawstwa w klasztorze.

Władze sądziły, że opozycja wobec przeora Rejmana powstała w klasztorze z powodu jego rzekomego „posłuszeństwa” władzom państwowym. Według Tiażelnikowa przyczyną jego odsunięcia było jednak tolerowanie przez niego naruszeń zakonnej obserwancji. Potwierdził to między innymi znany już wcześniej Tiażelnikowowi o. Romuald Dziemiadowicz.

Wysłannik przekonał się, że nowowybrany przeor o. Justyn Weloński nie jest wcale takim zgrzybiałym starcem, jak o nim sądzono. $Z$ jasnym umysłem uczestniczył np. do godz. $2 \mathrm{w}$ nocy w przesłuchaniu. Tiażelnikow stwierdził ponadto, że biskup kujawsko-kaliski Stanisław Zdzitowiecki ${ }^{11}$, który sygnalizował władzom potrzebę zwolnienia o. Rejmana z funkcji przeora „z powodu choroby” i zatwierdzenia o. Welońskiego, ukrył rzeczywisty stan rzeczy, jakim były wybory nowego przeora, przeprowadzone pod przewodnictwem wizytatora apostolskiego, karmelity z Krakowa, o. Chryzostoma Lamosza, który do Częstochowy przyjeżdżał trzykrotnie.

Rewizor zwrócił też uwagę na rolę, którą w klasztorze odgrywał o. Pius Przeździecki, wcześniej znajdujący się na zesłaniu, a potem wyjeżdżał za granicę. Powrócił jednak do klasztoru, ponieważ bp Zdzitowiecki nie zezwolił mu na jego opuszczenie. Tiażelnikow podejrzewał, że o. Przeździecki tajnie kontaktował się ze Stolicą Apostolską, co traktowano jako duże przestępstwo.

Ponadto Tiażelnikow zauważył następujące naruszenia prawa: w klasztorze przebywało dużo służących, były prowadzone nielegalnie kursy teologicznie dla nowicjuszy, w klasztorze zamieszkiwali kapłani diecezjalni, niektórzy, co prawda, za pozwoleniem władz. Jako naruszenie prawa ocenił też prowadzenie ksiąg finansowych w języku polskim. W. Tiażelnikow stwierdził, że wybranie przez kapitułę nowego przeora Welońskiego odbyło się nielegalnie w stosunku do prawa państwowego.

Zaproponował następującą drogę naprawy tego, co dokonane zostało z naruszeniem prawa państwowego. Jeśli chodzi o wybór przeora Welońskiego, który w rzeczywistości był najlepszym kandydatem na przeora, Tiażelnikow zasugerował kompromis, polegający na tym, aby kapituła wybierała swoich kandydatów na przeora i definitorów, jednak zatwierdzać ich powinna władza państwowa przy udziale biskupa. Proponował bądź zamknąć klasztor, bądź zalegalizować wybór Welońskiego. Pod nieobecność Skałona, p.o. warszawskiego genrał-gubernatora A. O. Essen ${ }^{12}$ zatwierdził wnioski Tiażelnikowa ${ }^{13}$.

i dobroczynnych oraz parafiach. Por. B. Czaplicki, Katolicka działalność dobroczynna w Rosji w latach 1860-1918, Warszawa 2008, s. 247.

${ }^{11}$ Stanisław Zdzitowiecki (1854 - 1927). Ukończył seminarium w Warszawie. Wyświęcony na kapłana w 1877. Odbył studia w Rzymie. W 1902 r. został biskupem diecezji kujawsko-kaliskiej, do której należała Częstochowa. Często odwiedzał Jasną Górę.

${ }^{12}$ Essen Anton Ottowicz (1863-1919). W latach 1905-1910 gubernator piotrkowski, potem zastępca warszawskiego generał-gubernatora. Zabity w Kijowie w 1919.

${ }^{13}$ RGIA, F. 821, op. 128, d. 173, k. 57-61 - Raport Tiażelnikowa 
Chociaż gubernator piotrkowski Jaczewski był przeciwny zatwierdzeniu o. Justyna Welońskiego na stanowisku przeora $\mathrm{z}$ tego powodu, że był on starcem, generał-gubernator Skałon 5 października 1910 r. zatwierdził go na tym stanowisku $^{14}$

Sprawą Częstochowy zajął się sam minister spraw wewnętrznych i premier rządu rosyjskiego Piotr A. Stołypin. Nie godził się z decyzją biskupa S. Zdzitowieckiego, który na Jasnej Górze wprowadził tymczasowy zarząd, składający się z kilku kapłanów diecezjalnych, ani też nie chciał zatwierdzić wybranego przez kapitułę przeora Justyna Welońskiego, ponieważ prawodawstwo rosyjskie zlikwidowało kapituły w klasztorach. Zebranie się jasnogórskiej kapituły odbyło się więc bezprawne. 2 października 1910 został przez Stołypina oddelegowany do Częstochowy wysoki urzędnik, naczelnik wydziału DDDII - A. W. Pietrow. On to zasugerował 7 października 1910 r. dyrektorowi DDDII A. N. Charuzinowi usunięcie z Jasnej Góry kapłanów diecezjalnych, którym biskup kujawsko-kaliski S. Zdzitowiecki powierzył kierowanie klasztorem. Wezwał on na Jasną Górę biskupiego wizytatora klasztorów, który zgodnie z prawem państwowym powinien był znać sytuację klasztoru i za nią odpowiadać ${ }^{15}$.

Po powrocie do Petersburga 15 października 1910 Pietrow złożył Stołypinowi raport o wykonaniu zadania. Postępowanie biskupa S. Zdzitowieckiego, który zamiast działać przez wizytatora klasztorów, wprowadził komisyjny zarząd na Jasnej Górze, określił jako bezprawne. Pietrow podkreślił ponadto, że zmiany w klasztorze nastąpiły w obecności apostolskiego wizytatora o. Ch. Lamosza. Ponieważ prawo rosyjskie zabraniało ingerencji osób z zagranicy w sprawy rosyjskie, dlatego takie postępowanie nazwał bezprawnym.

Pietrow zauważył jednak, że wybrany przeor Weloński jest właściwie jedynym człowiekiem $\mathrm{z}$ autorytetem, który jest $\mathrm{w}$ stanie zjednoczyć podzielonych zakonników. O. Piusa Przeździeckiego ocenił jako gorliwego zakonnika o niebezpiecznych narodowych przekonaniach. Zaproponował jego ukaranie, ponieważ on był oskarżany o zredagowanie i opublikowanie w prasie „Odezwy” paulinów do społeczeństwa polskiego po przykrych zajściach w klasztorze ${ }^{16}$. Odnotował

${ }^{14}$ RGIA, F. 821, op. 128, d. 173, k. 75 - Wycinki z „Kuriera Warszawskiego” nr 288.

${ }^{15} \mathrm{~W}$ normalnych warunkach problemy w klasztorach rozwiązywały wyższe władze zakonne, z Kongregacją Biskupów i Zakonników na czele. Państwo rosyjskie zlikwidowało wyższe władze zakonne oraz zabroniło kontaktów z Rzymem nieoficjalną drogą. Kontakt był możliwy tylko za pośrednictwem rządu rosyjskiego. Por. RGIA, F. 821, op. 128, d. 173, k. 51 - Pietrow do Charuzina 7 X 1910.

${ }^{16}$ „Odezwa” została opublikowana 5 października 1911 r. Paulini odcięli się od zbrodniarzy i prosili o sprawiedliwą ocenę wobec nich. Por. M. Jastrzębiec, Wobronie Jasnej Góry, Poznań 1911, s. 141-143. Cytowana praca jest polemiką z głosami, domagającymi się wypędzenia paulinów z Jasnej Góry i oskarżającymi katolickie duchowieństwo. Autorka broszury, pochodząca prawdopodobnie z kręgu ojca Piusa Przeździeckiego, przytoczyła apele biskupów, którzy wzywali do poprawy życia nie tylko świeckich, lecz także i kapłanów. Podkreśliła także, że konwent pauliński został ukarany przez władze rosyjskie nie za to, że na Jasnej Górze dokonała się zbrodnia, lecz za to, że paulini odważyli się dokonać uzdrowienia swojego konwentu. Nie interesowały się one znalezieniem winnych zbrodni, lecz takimi sprawami, jak: przyjazdy na Jasną Górę wizytatora apostolskiego, o. karmelity Ch. Lamosza, odnowienie przez zakonników kapituły, próby zaprowadzenia studiów 
też brak porządku w prowadzeniu ksiąg finansowych oraz prowadzenie ich po polsku. Proponował likwidację wszelkich zabronionych przez prawo państwowe stanowisk w klasztorze i nielegalnie otwartych kursów formacyjnych dla nowicjuszów. W obecności Pietrowa przeprowadzono kontrolę ofiar, składanych na Jasnej Górze.

Wysłannik DDDII zaproponował premierowi zlikwidowanie wywalczonych niegdyś przez przeora Euzebiusza Rejmana przywilejów dla Jasnej Góry, to znaczy pozwolenia imperatora z 1908 r. na zwiększenie limitu zakonników i zezwolenia ministerstwa spraw wewnętrznych z 1909 r. na obniżenie wieku kandydatów do klasztoru. Zażądał zerwania wszelkich kontaktów klasztoru z Rzymem i niedopuszczania do klasztoru duchowieństwa z zagranicy.

Pietrow dopuszczał wydalenie o. P. Przeździeckiego z klasztoru, lecz uważał to za niewskazane, ponieważ o. Pius był nienaganny pod względem obserwancji zakonnej. Premier Stołypin zaakceptował wnioski Pietrowa ${ }^{17}$. Bardziej szczegółowy raport Pietrow złożył 18 października.

DDDII interesował się także przyjazdem do Częstochowy na początku października 1910 r. redemptorysty z Warszawy, o. Bernarda Łubieńskiego. Zakonnicy jakoby niechętnie uczestniczyli w rekolekcjach, uważając, że przyjazd o. Bernarda był zainicjowany przez duchowieństwo diecezjalne. Oświadczyli oni redemptoryście, że nie mogą uczestniczyć w rekolekcjach z powodu stałych przesłuchań ${ }^{18}$.

Władze dowiedziały się ponadto, że biskupi Nadwiślańskiego kraju spotykali się 7 października w Warszawie w celu omówienia sprawy klasztoru częstochowskiego i postanowili zwrócić się do wiernych z wezwaniem do modlitwy przebłagalnej za popełnione w klasztorze grzechy. Stwierdzono, że spotkanie było zorganizowane nielegalnie, ponieważ nikt z uczestniczących w nim biskupów, nie prosił o pozwolenie na jego odbycie ${ }^{19}$. Dlatego indagowano w tej sprawie arcybiskupa warszawskiego Wincentego Popiela ${ }^{20}$.

Jesienią 1910 r. wspomniany wcześniej urzędnik W. Tiażelnikow przeszedł do pracy w DDDII. Odznaczył się wielką dociekliwością podczas przeprowadzenia śledztw w wielu katolickich placówkach.

seminaryjnych dla kandydatów oraz zaprowadzenie ksiąg w języku polskim. To za te przewinienia klasztor został ukarany przez cara. Cofnięto mu wywalczone przez o. Rejmana przywileje: prawo przyjmowania większej ilości kandydatów i obniżenie wieku kandydatów. Badane przeze mnie dokumenty rosyjskie potwierdzają trafność spostrzeżeń autorki.

${ }^{17}$ RGIA, F. 821, op. 128, d. 173, k. 105-118 - Služebnaâ zapiska A. V. Pietrova 15 X 1910. Winą Przeździeckiego było zredagowanie i opublikowanie 5 października 1911 r. „Odezwy”. Por. M. Jastrzębiec, W obronie Jasnej Góry, Poznań 1911, s. 141-143.

${ }^{18}$ RGIA, F. 821, op. 128, d. 173, k. 228-228 odwr. - Kancelariâ gen-gubernatora do DDDII 25 XI 1910.

${ }^{19}$ Biskupi ze wszystkich zaborów wzywali do ekspiacji i ostrożności w sądach, różne grupy społeczne wyrażały swoją więź z atakowanym Kościołem. Por. np. Kronika powszechna. Z Królestwa, „Przegląd Katolicki” 42 (1910) s. 836-837.

${ }^{20}$ Popiel-Chościak Wincenty Teofil (1825-1912). W 1863 został biskupem płockim. W 1868 zesłany do Nowgorodu Wielkiego. Po powrocie w 1876-1883 - bp kujawsko-kaliski we Włocławku. Od 1883 do śmierci - arcybiskup warszawski. 
4 grudnia 1910 r. premier Stołypin przedstawił carowi Mikołajowi II sprawę Częstochowy. Odnotował szereg naruszeń prawa, stwierdzonych w czasie śledztw przeprowadzonych przez Tiażelnikowa i Pietrowa. Zaproponował, nie dotykając wyróżnień przyznanych klasztorowi przez Stolicę Apostolską ${ }^{21}$, cofnąc przywileje udzielone klasztorowi przez cesarza. Oznaczało to wycofanie się cara z wcześniejszej zgoda na zwiększenie stanu osobowego klasztoru do 50 osób i obniżenie wieku kandydatów ${ }^{22}$. Imperator 5 grudnia 1910 r. wydał zgodę na decyzje Stołypina ${ }^{23}$.

Zgromadzone w badanej teczce wycinki z gazet pokazują, że dla DDDII niejednokrotnie inspiracją dla podjęcia działań wyjaśniających były informacje, opublikowane w gazetach. Wiele wysiłku poświęcono wyjaśnieniu, czy do Częstochowy rzeczywiście przyjeżdżał w charakterze wysłannika Stolicy Apostolskiej ksiądz ze Lwowa o nazwisku Nowowiejski. Na końcu opasłej teczki 173 znajduje się informacja, że korzystał z niej do celów naukowych ks. A. Jędrzejewski w dniu 5 listopada 1919 r., prawdopodobnie przed swoim wyjazdem z Piotrogrodu ${ }^{24}$.

Teczka nr 174 w 128 sygnaturze 821 zespołu RGIA dotyczy delegacji pracownika DDDII W. Tiażelnikowa na przewód sądowy, który miał się odbyć w Piotrkowie Trybunalskim i rozpatrywać kulisy zbrodni na Jasnej Górze. Sprawę podjęto 30 stycznia 1912 r. Po porozumieniu się ministerstw spraw wewnętrznych i sprawiedliwości i po ustaleniu daty sprawy sądowej, urzędnik został oddelegowany do Piotrkowa 8 lutego 1912 r. $^{25}$. Udawał się on najpierw do Warszawy, gdzie na prośbę DDDII miał się zapoznać z wynikami śledztwa w sprawie zgromadzeń honorackich ${ }^{26}$.

Miał także przesłuchać „swojego dawnego znajomego”, paulina o. Romualda Dziemiadowicza w związku z jego listem do dyrektora DDDII E. W. Mienkina ${ }^{27}$. Dziemiadowicz przekazał wtedy Tiażelnikowowi informacje o o. Przeździeckim, o jego wyjazdach do Rzymu, o sercankach, o publikacji apelu paulinów, o przeorze Welońskim ${ }^{28}$.

Po zakończeniu swojej misji 1 marca 1912 r. Tiażelnikow napisał dla ministra spraw wewnętrznych raport o przebiegu sprawy sądowej w Piotrkowie. Nie wdawał się w analizę doniesień prasowych, które podkreślały domniemaną winę rządu rosyjskiego w tej sprawie. Tiażelnikow zwrócił jednak uwagę na rolę o. Piusa Przeździeckiego i zaproponował usunięcie go z klasztoru ${ }^{29}$. Jego winą było

\footnotetext{
${ }^{21}$ Chodziło o prawo noszenia przez przeora szat infułata i o tytuł bazyliki, przyznany kościołowi jasnogórskiemu.

${ }^{22}$ RGIA, F. 821, op. 128, d. 173, k. 229-232 - Vsepoddannejšij doklad ministra 4 XII 1910.

${ }^{23}$ RGIA, F. 821, op. 11, d. 85 - Vsepoddannejšie doklady ministra VD po DDDII za 1910 g., $\mathrm{k}$. 23-26 - [Zgoda Mikołaja II 5 XII 1910].

${ }^{24}$ RGIA, F. 821, op. 128, d. 173, k. 292 - Služebnaâ zapiska.

${ }^{25}$ RGIA, F. 821, op. 128, d. 174, k. 1-7 - Komandirovka Tâželnikova 8 II 1912.

${ }^{26}$ RGIA, F. 821, op. 128, d. 174, k. 8 - DDDII - direktoru kancelarii Harlamovu 8 II 1912.

${ }^{27}$ RGIA, F. 821, op. 128, d. 174, k. 12 - telegram wicedyrektora DDDII Pawłowa do gubernatora Jaczewskiego 22 II 1912.

${ }^{28}$ RGIA, F. 821, op. 128, d. 174, k. 62-63 - protokol doprosa Demâdoviča 23 II 1912.

${ }^{29}$ RGIA, F. 821, op. 128, d. 174, k. 17-31. Warto tu odnotować relację, jaką na ten temat zapisał o. Honorat Koźmiński: „Tiażelnikow wyrzucał paulinom, że takiego zbrodniarza przyjęli. Na to
} 
kontaktowanie się ze Stolicą Apostolską, uzurpowanie sobie roli przeora jasnogórskiego w celu wpływania na kierunek formacji zakonników i pątników oraz opieka nad tajnymi zgromadzeniami zakonnymi, zajmującymi się działalnością oświatową ${ }^{30}$. O. Pius Przeździecki został w konsekwencji rzeczywiście wydalony z Częstochowy ${ }^{31}$.

O. Romuald Dziemiadowicz w dalszym ciągu świadczył DDDII usługi. Posyłał do Petersburga dla dyrektora Departamentu DDII informacje, np. 7 i 9 kwietnia 1912 r. $^{32}$, a także i później.

Ze zmianami na Jasnej Górze, polegającymi na wprowadzeniu ściślejszej karności, nie mogli pogodzić się także inni zakonnicy ${ }^{33}$. Oprócz o. Romualda Dziemiadowicza opozycjonistami byli o. Alfons Jędrzejewski i o. Aleksy Łuczaj. Ich krytyka dotykała także i biskupa kujawsko-kaliskiego, Stanisława Zdzitowieckiego. Dla uspokojenia sytuacji w klasztorze, o. Alfons został wysłany do Koła ${ }^{34}$, a o. Aleksy, po opuszczeniu zakonu, był skierowany do Włocławka. Raporty naczelnika powiatu częstochowskiego Secuły z 6 marca 1914 r. i 2 kwietnia 1914 r. świadczą o jego obiektywizmie i niedowierzaniu piszącym donosy ${ }^{35}$.

mu odpowiedział o. Pius [Przeździecki], że to wina rządu, bo nam nie wolno ani na jeden dzień przyjąć aspiranta, żeby mu się przypatrzeć, tylko rząd ich przyjmuje. - A to jakim sposobem? Według przepisu, kto chce wstąpić, pisze najpierw do gubernatora, ten żąda opinii od naczelnika straży. Naczelnik pisze do strażnika, a ten dostaje rubla i daje świadectwo, że jest „błagonadiożny” [budzący nadzieję - obj. ks. B. Cz.] i przyjeżdża do klasztoru z poleceniem gubernatora, aby był przyjęty. A jeśli się go w czymś napomni, zasłania się rozkazem gubernatora, a gdyby nawet udać się do gubernatora, to przyślą na śledztwo i zawsze pokaże się, że nie ma powodu do wydalenia". Por. H. Koźmiński, Objaśnienia tyczace się zgromadzeń ukrytych przed światem, w: „Nasza Przeszłość. Studia z dziejów Kościoła i kultury katolickiej w Polsce”, Red. ks. A. Schletz CM, t. XXVIII, Kraków 1968, s. 247.

30 Obszerny materiał z podaniem adresów i,,win” zawiera doniesienie piotrkowskiego gubernatora do warszawskiego generał gubernatora. Por. AJG 2249, Tajne pisma gubernatorów i naczelników policji (kopie) dotyczące o. P. Przeździeckiego, s. 41-51 - Gub. piotrkowski do warszawskiego gen.-gubernatora 30 IV 1912.

${ }^{31}$ Zaproponowano mu dwie możliwości: mógł udać się na zesłanie do guberni permskiej pod Ural, lub też wyjechać za granicę. O. Pius wybrał drugą możliwość. 21 lipca 1912 r. wyjechał do Krakowa. Por. AJG 2249, Tajne pisma gubernatorów i naczelników policji (kopie) dotyczące o. P. Przeździeckiego, s. 59 - Gubernator piotrkowski - do Gen.- gubernatora warszawskiego 2 IX 1912.

${ }^{32}$ RGIA, F. 821, op. 128, d. 174, k. 77-79 odwr. - Dziemiadowicz do Mienkina.

${ }^{33}$ Por. RGIA, f. 821, op. 128, d. 177 - Naczelnik powiatu Częstochowskiego - do gubernatora piotrkowskiego 2 IV 1914 r. Naczelnik powiatu Częstochowskiego - do gubernatora piotrkowskiego 20 III 1914.

${ }^{34}$ Świadek tych wydarzeń, lecz chyba nie do końca zorientowany w zakulisowej grze współbraci, o. Piotr Markiewicz w swoich wspomnieniach napisał, że w „marcu 1914 r. poniosła Jasna Góra dotkliwą stratę, mianowicie bp Zdzitowiecki, jako wizytator klasztoru, by ratować przed zamknięciem przez rząd klasztor oo. Bernardynów w Kole, po śmierci ostatniego gwardiana przeniósł tam, i mianował przełożonym (...) o. Alfonsa Jędrzejewskiego". Por. AJG 2440, o. Piotr Markiewicz, Kronika Zakonu Paulinów, s. 42.

${ }^{35}$ Dokumenty archiwalne, pochodzące z RGIA, [f. 821, op. 128, d. 177] - Čenstohovskij paulinskij monastyr', opublikowane w: SC 18 (1998) s. 351-358. 
Teczka zawiera też materiały, dotyczące zainteresowania się o. Rejmanem ze strony śledczego siedleckiego sądu okręgowego, co odnotowujemy też przedstawiając dokumenty w APŁ. 26 stycznia 1912 r. tenże śledczy z Siedlec zwracał się do DDDII o materiały ze śledztwa przeprowadzonego w Częstochowie w 1910 r. przez Pietrowa. Odpowiednie materiały zostały wysłane ${ }^{36}$. Nie można na podstawie tych materiałów stwierdzić, dlaczego sąd w Siedlcach rozpoczął sprawę przeciwko o. Rejmanowi w czasie, gdy jego już nie było w granicach Rosji.

Następne dokumenty świadczą o wysiłkach, czynionych w celu odrodzenia konwentu częstochowskiego. Wydatną rolę w tym zakresie odgrywał bp S. Zdzitowiecki, widocznie informowany przez o. Welońskiego i o. Przeździeckiego. Nie było łatwo usunać z klasztoru pięciu kleryków: Morawskiego, Adamczyka, Janiaka, Gruszki i Błażejewicza. Biskup wielokrotnie interweniował w sprawie ich usunięcia nie tylko u gubernatora, lecz również w ministerstwie spraw wewnętrznych. Ministerstwo skłonne było uwierzyć objaśnieniom kleryków, że są prześladowani, jako zwolennicy byłego przeora Rejmana, jednak w końcu wydało zgodę na ich usunięcie ${ }^{37}$.

14 stycznia 1913 r. „stary znajomy” Tiażelnikowa (o. Dziemiadowicz) informował DDDII o proponowanych w klasztorze zmianach, to znaczy o próbach naznaczenia pod wpływem nieobecnego już w klasztorze o. Piusa Przeździeckiego młodych ojców: Markiwicza na wikariusza, a Olszewicza na prokuratora klasztoru $^{38}$.

W latach 1913 - 1914 do klasztoru zaczęło zgłaszać się coraz więcej kandydatów-kapłanów ${ }^{39}$. O przyjęcie do klasztoru starał się m. in. ks. Jakowski z Częstochowy. Dzięki przyjęciu do klasztoru szeregu gorliwych kapłanów Jasnogórski konwent odrodził się przed samym upadkiem panowania rosyjskiego w Częstochowie. Nastąpiła nowa era w historii Jasnej Góry.

Następne teczki o numerach 175 i 176 w 128 sygnaturze 821 zespołu RGIA zawierają praktycznie jedynie wycinki z gazet, dotyczące $w$ przeważającym stopniu spraw kryminalnych, związanych z Jasną Górą. Nie wnoszą one nic ważnego. Autorzy artykułów w gazetach, poszukując taniej sensacji, powtarzali bowiem różne niesprawdzone wiadomości i wymysły.

${ }^{36}$ RGIA, F. 821, op. 128, d. 174, k. 83-85 - Sudebnyj sledovatel'- v DDDII 26 I 1912.

${ }^{37}$ Inicjatorem ich usunięcia nie był sam biskup, lecz najprawdopodobniej przeor Weloński i o. Przeździecki. Klerycy, nie życzący sobie poddać się karności zakonnej, żądali od biskupa przeprowadzenia w swojej sprawie sądu kanonicznego, co wskazuje na to, że w klasztorze mieli doradców. Por. RGIA, F. 821, op. 128, d. 174, k. 122-153 odwr. - Korespondencja między biskupem Zdzitowieckim, gubernatorem piotrkowskim, generał-gubernatorem, DDDII

${ }^{38}$ RGIA, F. 821, op. 128, d. 174, k. 185-187 - Načelnik kraâ - episkopu Zditovickomu 12 X 1912.

39 Do DDDII docierały informacje, że biskupi Nadwiślańskiego Kraju w celu ratowania Jasnej Góry postanowili do częstochowskiego klasztoru kierować kapłanów diecezjalnych, predysponowanych do życia zakonnego. Por. RGIA, F. 821, op. 128, d. 174, k. 121-145 korespondencja z DDDII. 


\section{Dokumenty o Jasnej Górze w Archiwum Państwowym w Lodzi (przegląd)}

Archiwum Państwowe w Łodzi posiada dużą ilość dokumentów, wypracowanych przez urzędy guberni piotrkowskiej, do której należały w czasach carskich zarówno Łódź, jak i Częstochowa. Archiwiści, którzy opracowali ich inwentarze, we wstępach do nich podają informację, że archiwum urzędów guberni piotrkowskiej zostało w 1914 r. przed wkroczeniem do Piotrkowa Trybunalskiego wojsk niemieckich wywiezione do Saratowa nad Wołgą. Materiały te, nie inwentaryzowane, a więc niedostępne dla badaczy, pozostawały tam przez kilka dziesięcioleci. Część ich uległa zniszczeniu pod wpływem warunków naturalnych, np. pleśni. Dopiero w latach siedemdziesiątych XX w. dokumenty z tego zasobu zostały przekazane PRL i umieszczone w Archiwum Państwowym w Łodzi (APŁ). Nie wiemy, czy przed przekazaniem dokumentów, nie dokonano jakiejś ich selekcji. Pracownicy APŁ zinwentaryzowali większość otrzymanych dokumentów, brakując te, które nie nadawały się do użytku. Trudno na tej podstawie ocenić, jaka część archiwum urzędów guberni piotrkowskiej się zachowała. Nie wiemy też, czy jakieś dokumenty nie zostały zniszczone przed ich wywiezieniem z Piotrkowa lub też czy nie przepadły w warunkach wojny.

We wrześniu 2009 r. przeprowadziłem kwerendę w łódzkim archiwum, poszukując dokumentów, dotyczących Jasnej Góry. Wśród zespołów APŁ nie ma oddzielnego „kościelnego” zespołu akt, jak to jest np. w RGIA w Petersburgu. Dokumentów, dotyczących Kościoła katolickiego, i konkretnie klasztoru na Jasnej Górze, należało więc szukać w różnych zespołach. Materiały, odnoszące się do Jasnej Góry, można znaleźć w zespołach: „Kancelaria gubernatora piotrkowskiego" i „Wydział Administracyjny rządu guberni piotrkowskiej”. W zespołach: „Piotrkowski sąd okręgowy”, „Piotrkowski prokurator okręgowy”, „Więzienie piotrkowskie" oraz innych nie znalazłem materiałów dotyczących Jasnej Góry.

Należało sięgnąć po dokumenty nie odnoszące się wprost do Jasnej Góry, lecz mogące się w jakiś sposób z nią wiązać. Zbadałem na przykład teczkę personalną o służbie państwowej jednego $\mathrm{z}$ wieloletnich gubernatorów piotrkowskich Konstantego Millera ze względu na jego znaną mi skądinąd aktywność w sprawie niszczenia Jasnej Góry. Przebadałem też dokumentację, dotyczącą śledztwa w klasztorze kapucynów w Nowym Mieście nad Pilicą, związanego z aktywnością zakonotwórczą o. Honorata Koźmińskiego.

Całość badanej dokumentacji sporządzona została w języku rosyjskim. Niektóre dokumenty, zwłaszcza rękopisy, trudno odczytać. Najtrudniej odczytać ręczne rezolucji i decyzje, umieszczane przez wysokich urzędników rosyjskich wprost na dokumentach, adresowanych do nich. Jedynie niewielka część badanych dokumentów została napisana na maszynie. Ponieważ Jasną Górą interesowała się policja, zbadałem też sprawozdania policyjne zwłaszcza z lat 1909 - 1910.

Często zdarza się, że w badanych poszytach nie umieszczono numeracji stron, kartek lub dokumentów. W takim wypadku trudno o dokładne ich cytowanie. 


\section{Jasna Góra w materiałach zespołu: „Kancelaria gubernatora piotr- kowskiego".}

Materiały dotyczące spraw religijnych, klasztorów ${ }^{40}$, w tym też samej Jasnej Góry, znajdujemy w zespole: „Kancelaria gubernatora piotrkowskiego”. Niektóre teczki mają w swojej nazwie słowo: „sekretno” (tajne). Np. poszyt 1744 nosi nazwę: „Obŝaâ sekretnaja i soveršenno sekretnaja perepiska” (Korespondencja ogólna tajna i całkowicie tajna). Znajduje się tam nie odnosząca się wprost do Jasnej Góry, korespondencja między powiatowymi naczelnikami i kancelarią gubernatora piotrkowskiego, dotycząca odebrania księżom i zakonnikom prawa potwierdzania tożsamości osób, otrzymujących przekazy pieniężne pocztą. Osoby duchowne pozbawiano takiego prawa, w celu obniżenia ich autorytetu wśród ludności.

Teczka 1761 dotyczy śledztwa, podjętego przez DDDII w sprawie obrazków i medalików z napisami o polskiej treści patriotycznej, które znajdowano w głębi Rosji, np. u żołnierzy - Polaków. Stwierdzono, że były one sprzedawane w Częstochowie przez kilku sklepikarzy, którzy w efekcie zostali surowo ukarani. Śledztwo to nie dotknęło jednak Jasnej Góry, ponieważ indagowani sklepikarze wyjaśniali, że przedmioty te sprowadzali z Austrii.

W zespole Kancelarii gubernatora piotrkowskiego znalazły się $\mathrm{m}$. in. sprawy, dotyczące pozwoleń na wyjazdy zagraniczne. W teczce 1734 znajdujemy np. dwa podania (z 30 stycznia i 12 lutego 1910 r.) bpa kujawsko-kaliskiego S. Zdzitowieckiego do gubernatora piotrkowskiego z prośbą o zagraniczny paszport dla ówczesnego przeora Jasnej Góry, o. Euzebiusza Rejmana, celem wyjazdu do San Remo. Gubernator pozytywnie zaopiniował tę prośbę, a warszawski generał-gubernator wydał zgodę na wyjazd. Jednak o. Rejman w efekcie nie wyjechał.

Prawdopodobnie chodziło wówczas o znalezienie podstawy do wyjazdu o. E. Rejmana do Rzymu w celu przywiezienia stamtąd do Częstochowy koron dla obrazu Częstochowskiego, ufundowanych przez Piusa X, w miejsce niedawno skradzionych. Sprawa oparła się o Departament Spraw Duchownych Wyznań Obcych, rząd rosyjski i samego cara. Kiedy car Mikołaj II wydał zezwolenie na przywiezienie do Częstochowy papieskich koron, ministerstwo spraw wewnętrznych 7 marca 1910 r. wydało zgodę na wyjazd o. Rejmana do Rzymu, a gubernator piotrkowski wystawił mu paszport zagraniczny. O. Rejman wraz z ks. Maxem z Włocławka mieli być oficjalną delegacją do Rzymu, aby przywieźć stamtąd korony dla obrazu MB Częstochowskiej ${ }^{41}$.

Gdy o. Rejman w 1911 roku ponownie starał się o wyjazd zagraniczny, gubernator piotrkowski M. E. Jaczewski nie wydał jemu takiego pozwolenia, uzasadniając swoją odmowę tym, że w Piotrkowie niebawem miała rozpocząć się rozprawa sądowa, dotycząca przykrych wydarzeń na Jasnej Górze (świętokradztwa i morderstwa). Ponieważ jednak piotrkowski prokurator okręgowy 16 lutego

${ }^{40} \mathrm{~W}$ tym czasie w guberni piotrkowskiej oprócz Jasnej Góry istniał klasztor kapucynów w Nowym Mieście nad Policą i dominikanek w Przyrowie.

${ }^{41}$ APŁ, Kancelaria gubernatora piotrkowskiego, Syg. 1734 - O rezrešenii zagraničnyh otpuskov r.-k. duhovenstvu pietrokovskoj guberni. 
1912 r. udzielił zgody na wyjazd o. Rejmana, gubernator 20 lutego zaalarmował generał-gubernatora warszawskiego, aby w obliczu trwającej w Piotrkowie rozprawy sądowej, zatrzymać w kraju o. Rejmana.

Gubernator zaznaczył jednak, że nie wie, jakie są zamiary rządu wobec Jasnej Góry. Sugerował, że jeśli rząd zamierza jedynie na przyszłość uporządkować prowadzenie sprawozdawczości finansowej na Jasnej Górze, a przeszłość puścić w niepamięć, to na wyjazd Rejmana można pozwolić. Jeśli jednak rząd pragnie zbadać sprawy poprzedniej administracji klasztoru, to nie należy pozwalać na wyjazd o. Rejmana. Rosyjskie ministerstwo spraw wewnętrznych zdecydowało jednak, aby nie przeszkadzać w wyjeździe o. Rejmanowi. Nie znaczy to jednak, że rosyjskie władze centralne przestały interesować się Jasną Górą. Zainteresowanie to trwało nadal, o czym świadczą inne dokumenty ${ }^{42}$.

Ta sama teczka zawiera np. sprawę pozwolenia na wyjazd za granicę (do Zakopanego) innemu zakonnikowi częstochowskiemu - o. Romualdowi Dziemiadowiczowi. Chociaż o tym pozwoleniu też zdecydował Departament DDII, to pozwolenie było wydane bez trudności. Jak zobaczymy, zakonnik ten później okazywał władzom swoją ,wdzięczność”.

Wśród dokumentów zespołu Kancelarii gubernatora znajdujemy też teczki z dokumentami, dotyczącymi śledzenia katolickich kapłanów, zakonników i kleryków przyjeżdżających na Jasną Górę z zagranicy. Poszukiwano m. in. niejakiego o. Primitivusa Krauze, bonifratra, który starał się o pozwolenie na przyjazd do Częstochowy, ale DDDII mu na to nie pozwolił. W tej samej teczce znajdujemy też nie związane z Jasną Górą dokumenty wzywające do śledzenia wydalonego z Rosji jezuity o. Feliksa Wiercińskiego ${ }^{43}$ oraz biskupa Franciszka Albina Symo$\mathrm{na}^{44}$. Tego pierwszego $\mathrm{w}$ ogóle wydalono $\mathrm{z}$ kraju, drugiemu pozwolono pozostać, jednakże bez prawa na służenie. Dokumenty pokazują, że po 1910 r. rosyjskie władze postanowiły zabronić wszystkim bez wyjątku księżom katolickim z zagranicy przyjazdu do Częstochowy.

Władze rosyjskie żywo interesowały się także mariawitami, a zwłaszcza tym, aby nie stała się im jakaś krzywda. Teczka 1770 poświęcona jest rzekomemu oblaniu kwasem przez księdza mariawickiego w Sali Rycerskiej na Jasnej Górze

${ }^{42}$ Por. M. Jastrzębiec, W obronie Jasnej Góry, Poznań 1911, s. 167-168.

${ }^{43}$ Feliks Wierciński - urodzony w Prusach. 9-klasowe gimnazjum ukończył w 1877. Potem uczył się w Kolegium Germanicum w Rzymie. Studia ukończył w 1887 r. Kapłanem został w 1885 r. Był kaznodzieją na Śląsku, m in. w Katowicach, potem był ojcem duchownym w seminarium duchownym w Breslau (Wrocławiu). W latach 1887 - 1903 pracował jako administrator w prowincji hanowerskiej. W 1905-1907 zajmował się badaniami naukowymi. W czasie składania relacji nie miał żadnego źródła dochodu. 30 X 1907 został naznaczony na stanowisko p. o. wikariusza kościoła św. Piotra i Pawła w Moskwie i wicedziekana moskiewskiego. Wyjeżdżał na urlop za granicę. Por. RGIA, F. 826, op. 1, d. 1745, 1. 11-12, Formulârnyj spisok...Vircinskogo.

${ }^{44}$ Franciszek Albin Symon (1841-1918). W 1884-1897 profesor i rektor Akademii Duchownej w Petersburgu. Od 1891 bp pomocniczy mohylowski. W 1897 nominowany na biskupa płockiego, lecz nie objął diecezji, gdyż został zesłany do Odessy, a potem został wydalony z Rosji. Zmarł w Krakowie. Por. A. Fajęcki, Biskupi naszej Almy, Warszawa 1938. 
swojej 15-letniej siostrzenicy, za to, że porzuciła ona mariawitów. Policmajster częstochowski Czesnakow wyjaśnił jednak, że takiego wydarzenia w ogóle nie było, a egzaltowana dziewczyna chciała jakoby stać się tak słynna jak Helena Krzyżanowska ${ }^{45}$.

Wśród dokumentów zespołu Kancelarii gubernatora piotrkowskiego znajdujemy kilka poszytów, zatytułowanych: „Perepiska po delam r.-k. monastyrej” (Korespondencja w sprawie klasztorów rzymskokatolickich). Teczka 1738 zawiera np. korespondencję, dotyczącą kandydatów, zgłaszających się do klasztorów ${ }^{46}$. Znajduje się w niej odręczny list o. przeora Rejmana do gubernatora piotrkowskiego z dn. 15 kwietnia 1910 r. z życzeniami wielkanocnymi i odpowiedź gubernatora na te życzenia.

Są w tej teczce też listy arcybiskupa warszawskiego W. Popiela i bpa kujawsko-kaliskiego S. Zdzitowieckiego do urzędów państwowych w sprawie przyjęcia kandydatów do klasztoru paulinów na Jasnej Górze i kapucynów w Nowym Mieście nad Pilicą. Arcybiskup warszawski zawiadomił np. gubernatora piotrkowskiego o planowanych ślubach zakonnych w Nowym Mieście, na których powinni byli uczestniczyć wydelegowani urzędnicy państwowi. Stanęło na tym, że naczelnik powiatu rawskiego, do którego należało Nowe Miasto, oddelegował na uroczystość złożenia ślubów dwóch urzędników, katolików.

Teczka ta zawiera też materiały dotyczące sprawy wyjazdów zakonników z klasztoru. P.o. generał-gubernatora warszawskiego Anton Ottowicz Essen zwrócił się z tą sprawą do warszawskiego ober-policmajstra (naczelnika policji na terenie Królestwa Polskiego) i wszystkich gubernatorów. Gubernator piotrkowski w odpowiedzi na jego pismo wysłał z kolei okólnik do naczelników powiatów i powiatowych policmajstrów z zapytaniem, jak wygląda sprawa wyjazdów zakonników z klasztorów i ich przyjazdów do miejscowości podległych ich jurysdykcji. Poprosił ich o wyrażenie opinii na temat administracyjnej i policyjnej kontroli tych wyjazdów. Odpowiedzi naczelników były zróżnicowane. Np. naczelnik powiatu częstochowskiego radził nie zwracać uwagi na wyjazdy zakonników. Piotrkowski naczelnik powiatu radził nie przeszkadzać w przyjazdach zakonników, ponieważ przyczyniają się oni do podniesienia moralności w okolicy. Inni naczelnicy byli mniej liberalni i żądali kontroli.

Wszyscy powiatowi policmajstrzy byli natomiast zwolennikami ścisłej kontroli wyjazdów i przyjazdów zakonników. Żądali, aby zakonnik uzyskiwał pozwolenie na wyjazd i po przyjeździe na miejsce, meldował się. Częstochowski policmajster np. 22 czerwca 1910 r. pisał do gubernatora, że musi być ścisła kontrola wyjazdu zakonników, gdyż oni, jako dobrzy spowiednicy i kaznodzieje, mogą wpływać na masy w sensie nacjonalistycznym. Proponował, aby przeor o każdym wyjeździe zakonnika z klasztoru donosił władzy, a ona, aby zawiadamiała odpowiednie organy państwowe w miejscu przyjazdu zakonnika. Proponował, aby władze wydawały paszport na każdy nawet niedaleki wyjazd i po przyjeździe

${ }^{45}$ Była sądzona w 1912 r. w Piotrkowie za współudział w przestępstwach na Jasnej Górze.

${ }^{46} \mathrm{~W}$ guberni piotrkowskiej były tylko trzy takie klasztory (jasnogórski, kapucynów w Nowym Mieście i dominikanek w Przyrowie). 
go odbierały. Sosnowiecki policmajster np. nie życzył sobie wcale przyjazdu zakonników, twierdząc, że głoszą oni kazania polityczne.

Gubernator piotrkowski Jaczewski nie był zadowolony z otrzymanych odpowiedzi. Na podstawie informacji, otrzymanej z powiatów, gubernator skierował „całkowicie tajny” raport do warszawskiego generał-gubernatora. Zaznaczył on na wstępie, że brak jest podstaw prawnych do ścisłego kontrolowania wyjazdów zakonników. Uskarżał się, że naczelnicy powiatów są zupełnie niezorientowani w nieprawnym postępowaniu zakonników. Był jednak zdecydowanie przeciwny wprowadzeniu ścisłej kontroli wyjazdów każdego zakonnika. Obawiał się, że w takiej sytuacji zakonnicy zamkną się i zdobycie jakieś informacji o klasztorach będzie bardzo trudne. Zaproponował, aby kontrolą zakonników nie zajmowali się pół-analfabeci, jakimi są członkowie straży ziemskiej (policja miejscowa), lecz miejscowe „Ochrannoje Otdelenije”, to znaczy Ochrana. Proponował następujące dwa sposoby inwigilacji klasztorów: umieszczenie w klasztorach agentury, podobnie, jak to uczyniono w partiach politycznych, i zewnętrzną, nieoficjalną obserwację. Przekonywał, że skoro polityczna agentura zdołała wejść w szeregi komitetów rewolucyjnych, to znajdzie drogę i do klasztorów ${ }^{47}$.

$\mathrm{W}$ teczce znajduje się też korespondencja między władzami i biskupami o zmianach w liczbie zakonników. Władze wymagały od biskupa informacji o tym, kto i dlaczego opuścił klasztor, kto umarł, kto pragnie wstąpić itd.

9 października 1910 r. częstochowski policmajster przekazał do kancelarii gubernatora dwie listy zakonników częstochowskich. Pierwsza zawierała 13 nazwisk zakonników etatowych. Na drugiej liście, zawierającej nazwiska zakonników nieetatowych, znajdowało się 8 osób, z adnotacją, że jedna z nich zmarła. Gubernator 16 XI 1910 przekazał tę listę do generał-gubernatora i przypomniał, że klasztor częstochowski ma prawo do 24 zakonników etatowych i 26 nieetatowych $^{48}$. Dalsza korespondencja, znajdująca się w teczce świadczy o tym, że później liczba zakonników w Częstochowie jeszcze bardziej się zmniejszyła.

Warszawski generał-gubernator zawiadomił 28 XI 1910 r. gubernatora piotrkowskiego, o swojej zgodzie na propozycję bpa S. Zdzitowieckiego, aby na stanowisko wizytatora klasztorów naznaczył ks. kan. Władysława Krynickiego.

Szczególną uwagę w zespole Kancelarii gubernatora piotrkowskiego budzi teczka 2832, nazwana: „O čenstohovskom monastyr'e” (Klasztor częstochowski). Warszawski generał-gubernator w $1912 \mathrm{r}$. powiadomił gubernatora piotrkowskiego o tym, że w 13 numerze nielegalnego periodyku „Polska” w listopadzie ubie-

${ }^{47}$ APŁ, Kancelaria gubernatora piotrkowskiego, Syg. 1738 - Perepiska po delam r.-k. monastyrej, Gubernator piotrkowski do gen.-gub. warszawskiego 2 IX 1910.

${ }^{48}$ Pojęcia wprowadzone przez represyjne prawodawstwo rosyjskie, prowadzące do stopniowej kasaty klasztorów. Według carskiego dekretu z 1864 r. jedne klasztory powinny były być od razu zlikwidowane, inne miały być skazane na wymarcie, a tylko niektóre uznano za etatowe, to znaczy przeznaczone do istnienia. Por. Archiwum Jasnej Góry (AJG), o. Piotr Markiewicz, Kronika Zakonu Paulinów, s. 2-4. 
głego (1911) roku opublikowano artykuł, poświęcony wyjaśnieniu stosunku rządu rosyjskiego do częstochowskiego klasztoru ${ }^{49}$.

W wymienionym artykule opublikowano materiały pochodzące jakoby z kancelarii gubernatora piotrkowskiego. Gubernator Jaczewski wyjaśnił generał-gubernatorowi, że żadne dokumenty z jego kancelarii nie zginęly, a opublikowane we wspomnianym czasopiśmie treści pochodzą z wydanej przez zmarłego byłego gubernatora piotrkowskiego K. Millera książki, która miała służyć jedynie do celów wewnętrznych i była przekazana niewielkiemu gronu najbliższych jego współpracowników. Właśnie w niej zamieszczony został $\mathrm{m}$. in. raport gubernatora Millera z 1903 r., w którym autor domagał się skasowania klasztoru jasnogórskiego, żałując, że nie zlikwidowano go już w $1864 \mathrm{r}^{50}$.

Wśród materiałów, pochodzących z Kancelarii gubernatora piotrkowskiego z 1912 r. znajdujemy też napisany na maszynie, podpisany po rosyjsku ,Jendrżeevskij", donos do gubernatora piotrkowskiego o sytuacji w klasztorze jasnogór$\operatorname{skim}^{51}$. Z treść donosu wynika, że jego autor był dobrze zorientowany w wewnętrznych sprawach klasztoru. Ostrzegał on gubernatora przed kapłanem z kościoła św. Zygmunta w Częstochowie, ks. Włodzimierzem Jakowskim, który jakoby codziennie od godz. szóstej rano do dwudziestej wieczorem przebywał w klasztorze i wtrącał się w jego sprawy. Ks. Jakowski nie ukrywał, że jest agentem Rzymu i że ma polecenie o wszystkim donosić. Zastępował on Piusa w klasztorze.

O. Przeździecki ${ }^{52}$, wyjeżdżając za granicę, przekazał mu jakoby wszystkie sekretne sprawy klasztoru. Jakowski, podobnie jak o. Pius, został nazwany przez autora donosu ,szowinistą" politycznym. Autor donosił ponadto, że w czasie pielgrzymki, która w lutym przybyła z Petersburga, nocą urządzono w klasztorze zebranie, na którym Jakowski opowiadał o prześladowaniu Kościoła katolickiego przez rząd. Kiedy przybyła policja, Jakowski i inni uczestnicy spotkania uciekli bocznym wyjściem. Ponieważ Jakowski pragnął wstąpić do klasztoru, autor donosu ostrzegał gubernatora, aby nie pozwolić mu na to, ponieważ zburzy on

49 Omawianą pozycję wydało nieznane Wydawnictwo Polski (możliwe, że Wydawnictwo czasopisma „Polska”).

${ }^{50}$ Por. APŁ, Kancelaria gubernatora piotrkowskiego, Syg. 2832 - O čenstohovskom monastyre, s. 1-2. Opublikowane dokumenty w rzeczywistości pochodziły z kancelarii gubernatora. Raport ten cytuje anonimowy autor książki: Tajne dokumenty rządu rosyjskiego. Rząd o Jasnej Górze. Dokumenty, dotyczace klasztoru oo. Paulinów na Jasnej Górze, Wyd. Polski, Kraków 1911, s. 83-84. Warto przy okazji odnotować, że zmarłemu piotrkowskiemu gubernatorowi K. Millerowi zdarzyła się na początku jego wojskowej kariery degradacja ze stopnia oficerskiego do szeregowca. Początek jego nowej kariery wiązał się z zasługami w tłumieniu powstania styczniowego. Por. APŁ, Kancelaria gubernatora piotrkowskiego, syg. 13372 - Gubernator K. Miller. Poslužnyj spisok o službe.

${ }^{51}$ APŁ, Kancelaria gubernatora piotrkowskiego, Syg. 2832 - O čenstohovskom monastyre.

${ }^{52}$ Władze policyjne i DDDII skupiły się na działalności o. Piusa Przeździeckiego. O dużym zainteresowaniu tym zakonnikiem świadczą dokumenty, wydobyte prawdopodobnie z kancelarii gubernatora piotrkowskiego, znajdujące się w Archiwum Jasnej Góry. Obejmują one lata 1911 1913. Por. AJG 2249 [Korespondencja urzędowa]. Na ostatniej stronie widnieje notatka o. Piusa: "Wszystkie 16 arkuszy zgodne z oryginałem. O. Pius Przeździecki". 
porządek na Jasnej Górze ${ }^{53}$. Należy się domyślać, że o nocnym spotkaniu w klasztorze $\mathrm{z}$ udziałem ks. Jakowskiego, ktoś doniósł na policję.

Gdy były przeor, o. E. Rejman wyjechał już za granicę, 27 maja 1912 r. kancelaria gubernatora piotrkowskiego zwróciła się do policmajstra częstochowskiego z prośbą, aby zatrzymać o. Rejmana, gdyby on pojawił się w Częstochowie, unikając jednak jego aresztowania. $Z$ taką prośbą wystąpił bowiem sędzia śledczy do spraw specjalnych przy okręgowym sądzie siedleckim. Nie podano jednak, do jakich celów potrzebny był o. Rejman ${ }^{54}$. Ta sprawa pojawia się także wśród materiałów RGIA w Petersburgu, na co zwracaliśmy wcześniej uwagę.

W latach 1912 - 1914 władze rosyjskie wydawały więcej pozwoleń na przyjęcie kandydatów do jasnogórskiego klasztoru. Okazało się jednak, że łatwiej było wstąpić do klasztoru, niż usunąć z niego niegodnego zakonnika. Na usunięcie zakonnika wymagana była bowiem zgoda ministra spraw wewnętrznych ${ }^{55}$.

Biskup Zdzitowiecki zdawał sobie sprawę, że aby podnieść prestiż Jasnej Góry, należy ulepszyć opiekę duszpasterską nad pielgrzymami. Wielokrotnie próbował na najwyższym szczeblu, to znaczy w petersburskim ministerstwie spraw wewnętrznych uzyskać pozwolenie na urządzenie w granicach zabudowań klasztornych rodzaju konwiktu dla kapłanów diecezjalnych, którzy śpieszyli z pomocą duszpasterską. Jednakże ministerstwo 14 lipca 1913 r. odmówiło pozwolenia na urządzenie mieszkań dla księży w pomieszczeniach, gdzie wcześniej mieszkali świeccy. Częstochowski policmajster sugerował, aby księża musieli wynajmować mieszkania $\mathrm{w}$ mieście, aby łatwiej było za nimi śledzićs ${ }^{56}$.

Być może bp Zdzitowiecki, podejmując inicjatywę urządzenia w klasztorze mieszkań dla księży diecezjalnych, pragnął w ten sposób ukryć swój pomysł odrodzenia życia duchowego klasztoru jasnogórskiego poprzez poddanie go kierownictwu odrodzonego niedawno zakonu marianów. Z taką myślą nosił się on już w 1910 r. Powracał do niej i później ${ }^{57}$.

W zespole „Zarząd żandarmerii powiatu częstochowskiego i noworadomskiego", znajdującym się również w APŁ nie znajdujemy dokumentów, związanych z rozprawą sądową, odbywającą się w Piotrkowie w 1912 r., dotyczącą wydarzeń na Jasnej Górze.

W zespole Kancelarii gubernatora piotrkowskiego znajdują się też dwie bardzo obszerne księgi duchowieństwa diecezjalnego i zakonnego guberni. Spis ten tworzony był przez władze państwowe. Zapisy prowadzono od 31 marca $1869 \mathrm{r}$. Teczka 9a) podaje na stronach 1139-1256 informacje o paulinach z Jasnej Góry.

${ }^{53}$ APŁ, Kancelaria gubernatora piotrkowskiego, Syg. 2832 - O čenstohovskom monastyre, s. 8.

${ }^{54}$ APŁ, Kancelaria gubernatora piotrkowskiego, Syg. 2832 - O čenstohovskom monastyre, s. 6-7. O. E. Rejman pozostał po tragicznych wydarzeniach w Częstochowie poza granicami kraju. Por. AJG 2205, 2206, 2207.

${ }_{55}$ APŁ, Wydział Administracyjny rządu gubernatora piotrkowskiego, Syg. 13307 (1912 r.), 13372 (1913 r.) - O peremenah v r.-k. monastyriah.

${ }^{56}$ APŁ, Kancelaria gubernatora piotrkowskiego, Syg. 2832 - O čenstohovskom monastyre, s. 13-39.

${ }^{57}$ AJG 2440, o. Piotr Markiewicz, Kronika Zakonu Paulinów, s. 34-35. 
Podano tam podstawowe dane biograficzne duchownego, informacje o zdobytym wykształceniu i miejscach służby. Przy niektórych nazwiskach znajdują się adnotacje o zachowaniu się, o postawionych zarzutach, czasem o śmierci.

Zgromadzeniom honorackim, roli samego o. Honorata i relacjom z mariawitami poświęcone są niektóre teczki z zespołu Kancelarii gubernatora piotrkowskiego. Np. w teczce 1732 zgromadzono dużą ilość wycinków prasowych, zawierających informacje o sprawach honorackich, które cytowały $\mathrm{m}$. in. demaskatorską publicystkę Stanisławę Poraj ${ }^{58}$.

Teczka 2833, zatytułowana jest: „O gonoratskih kongregaciâh” (Zgromadzenia honorackie). 27 lutego 1912 r. generał-gubernator Kraju Nadwiślańskiego zwrócił się do gubernatorów i warszawskiego ober-policmajstra z zapytaniem o zgromadzenia honorackie. Znamienne jest to, że dopiero w 1912 r. zainteresowano się artykułami w urzędowej gazecie „Warszawskij Dniewnik” z 1909 r. (a więc sprzed trzech lat) pt. „Mariawityzm i towarzystwa o. Honorata” oraz „Honoraty". Odkryto też list kard. Ferrata do o. Honorata ${ }^{59}$.

W celu zbadania poruszanych przez prasę faktów został przez generał-gubernatora wydelegowany starszy urzędnik do zadań specjalnych, Rodzianko. W jego śledztwie największą pomoc okazali mu dwaj biskupi mariawiccy (Jan Kowalski i Roman Próchniewski) oraz „mateczka” F. Kozłowska. Wyjaśnili oni, że odeszli od ruchu honorackiego i Kościoła katolickiego w tym celu, aby nie być poddani jezuitom. Rodzianko w swoim raporcie potwierdził rzeczywiste istnienie ukrytych wspólnot zakonnych. Ponieważ policja w Warszawie nie mogła dać sobie rady z wyśledzeniem tajnych klasztorów, zaproponował, aby dalszą rewizję prowadził specjalny korpus żandarmów ${ }^{60}$.

Policja i osobiście pan Rodzianko indagowali także samego, zamieszkałego wtedy w kapucyńskim klasztorze w Nowym Mieście nad Pilicą o. Honorata Koźmińskiego. Przesłuchiwano też personel różnych ośrodków katolickich, w których rzeczywiście pracowali członkowie ukrytych zgromadzeń. Takich zgromadzeń poszukiwano też w Częstochowie ${ }^{61}$. Rewizje były przeprowadzone np. u zamieszkujących w bezpośrednim sąsiedztwie Jasnej Góry ukrytych Małych Sióstr Niepokalanego Serca Maryi (sióstr fabrycznych). Policja chciała dowiedzieć się nie tylko tego, czy jest to zgromadzenie zakonne, lecz znaleźć potwierdzenie na to, że znajduje się ono pod wpływem paulina, o. Piusa Przeździeckiego ${ }^{62}$.

${ }^{58}$ Przybyła ona, jakoby w celu leczniczym, do Nowego Miasta i zamieszkała u honorackich sióstr służek. Zdobyła napisany przez o. Honorata podręcznik dla zgromadzeń ukrytych, na podstawie którego napisała i opublikowała po polsku i po rosyjsku w Warszawie w 1910 r. broszurę pt. „Tajne zakony honorackie (Nasza rodzima kabała pobożnych)". Ta broszura stała się sygnałem do szeroko zakrojonego poszukiwania ukrytych zgromadzeń zakonnych w całym państwie rosyjskim. Por. RGIA, F. 821, op. 150, d. 156, O tajnyh (gonoratskih) obŝestvah.

${ }^{59}$ APŁ, Kancelaria gubernatora piotrkowskiego, Syg. 2833 - O gonoratskih kongregaciâh (teczka bez paginacji).

60 APŁ, Kancelaria piotrkowskiego gubernatora, sygn. 2833 - O gonoratskih kongregaciâh, Raport Rodzianki, s. 1-23.

${ }^{61}$ AJG 2249, [Tajna korespondencja dot. o. Przeździeckiego], s. 29-30.

${ }^{62}$ M. Werner OSU, O. Honorat Koźmiński kapucyn 1822 - 1916, Pallotinum, Poznań Warszawa 1972, s. 432. 
Teczka zawiera m. in. informację o rewizji przeprowadzonej przez warszawski wydział Ochrany w księgarni Szczełkowskiego, w której znaleziono m. in. materiały honorackie. Jest to praktycznie jedyna znana mi akcja antykatolicka, w której zaangażowana była Ochrana. Rodzianko nie dostrzegał jednak w działalności wspólnot honorackich działań politycznych, lecz polskie narodowe ${ }^{63}$.

\section{Dokumenty w zespole: „Wydzial Administracyjny Rządu Guberni Piotrkowskiej" w APL.}

Dokumenty, dotyczące spraw kościelnych, możemy znaleźć w APŁ rozproszone w zespole: „Wydział Administracyjny Rządu Guberni Piotrkowskiej”.

Jedna $\mathrm{z}$ teczek tego zespołu, której numer nie został przeze mnie zanotowany, dotyczy zatwierdzenia przez władze w 1910 r. składu Komitetu do kontroli sum klasztoru częstochowskiego ${ }^{64} .21$ X $1910 \mathrm{r}$. naczelnik powiatu częstochowskiego wysłał do administracji gubernatora listę zaproponowanych członków Komitetu kontrolnego ${ }^{65}$. Byli na tej liście: Dominik Feliksowicz Klepacki, Ignacy Michajłowicz Tomczyk i Władysław Ludwikowicz Małkowski. Po uzyskaniu opinii o ich „błagonadiożnosti” w sensie politycznym i moralnym oraz złożeniu przez nich przysięgi na wierność carowi, gubernator zatwierdził skład Komitetu. Prezydent Częstochowy wydał wtedy sznurowaną księgę, służącą dla zapisywania ofiar. Już jednak 11 maja 1911 r. zmarł jeden z członków tego Komitetu. Należało więc wysłać gubernatorowi protokół o dołączeniu nowego członka Komisji i o złożeniu przez niego wymaganej przysięgi. Protokół ten podobnie, jak i poprzedni, podpisali zainteresowani, prezydent Częstochowy i przeor o. Justyn Weloński ${ }^{66}$.

W teczce 13199 z tego samego zespołu, znajdujemy dokumentację o składzie osobowym wszystkich trzech katolickich klasztorów guberni piotrkowskiej, oraz o wydawaniu zakonnikom zapomóg. Ministerstwo spraw wewnętrznych troszczyło się także o wsparcie materialne dla zakonników, którzy opuścili klasztor. Znajdujemy tam też informację o zatwierdzeniu przez gubernatora piotrkowskie-

${ }^{63}$ APŁ, Zesp. Kancelaria piotrkowskiego gubernatora, sygn. 2833 -O gonoratskih kongregaciâh, Raport Rodzianki, s. 1-23.

${ }^{64}$ Władze rosyjskie postanowiły zaostrzyć kontrolę sum pieniężnych, składanych na Jasnej Górze w postaci ofiar do puszek i ofiar na Msze święte.

${ }^{65}$ Chodziło o stworzenie pozorów, że ofiary, składane przez wiernych w klasztorze jasnogórskim są kontrolowane nie tylko przez władze państwowe, lecz i przez komitet społeczny, złożony z katolików.

${ }^{66}$ Władze państwowe wydały w 1874 r. specjalnie dla Jasnej Góry zasady rozliczania z napływających do klasztoru ofiar, w tym stypendiów mszalnych. Wszystkie skarbonki, w tym także ta, do której należało wrzucać ofiary na Msze święte, były opieczętowane przez władze państwowe. Po uprzednim zapisaniu przez dyżurującego zakonnika wysokości stypendium mszalnego w wydanej przez władze państwowe księdze, proszący wrzucał do skarbonki ofiarę. Ojcowie musieli więc tracić dużo czasu na biurokratyczne cele. Por. Przepisy o rachunkowości klasztoru Paulińskiego w Częstochowie, w: Tajne dokumenty rządu rosyjskiego. I. Rząd o Jasnej Górze. Dokumenty dotyczace klasztoru OO. Paulinów na Jasnej Górze, Kraków 1911. Wyd. Polski, s. 28-33. 
go na stanowisku przeora Jasnej Góry o. Justyna Welońskiego. Dokumentacja ta potwierdza, że państwo starało się kontrolować wszystkie środki pieniężne, trafiające $w$ jakiejkolwiek formie do klasztoru, a centralnie $z$ Petersburga decydowało o wydzielaniu sum na utrzymanie poszczególnych zakonników.

Podobne dane, dotyczące jednak 1912 roku, zawiera teczka nr 13307. Nosi ona nazwę: „O zmianach w składzie osobowym rzymskokatolickiego duchowieństwa zakonnego i o wypłacie im utrzymania". Na zamieszczonej w teczce liście zakonników jasnogórskiego klasztoru w Częstochowie figuruje 16 osób. Nazwisko o. Rejmana jest skreślone ${ }^{67}$.

22 lutego 1912 ministerstwo spraw wewnętrznych pozwoliło wstąpić do klasztoru ks. Mikołajowi Liburze, a także Antoniemu Lewandowskiemu i Leonowi Żabickiemu. Jednak już 6 kwietnia naczelnik powiatu doniósł gubernatorowi, że Lewandowski wystąpił, a Żabickiego nie przyjęto ze względu na brak powołania. 30 maja 1912 r. policmajster częstochowski doniósł administracji gubernatora, że 5 kleryków, zwolnionych z jasnogórskiego klasztoru, nadal tam przebywało. Z kolei naczelnik powiatu częstochowskiego raportował 16 sierpnia 1912, że te pięć osób (są podane ich nazwiska) zostało usuniętych 21 lipca 1912 r. ${ }^{68}$.

Podobnie jak omówione wyżej teczki (13179 i 13307), poszyt 13372 również zawiera dokumenty o zmianach w składzie personalnym zakonników i o wypłatach zapomóg dla nich. Jest to korespondencja pomiędzy różnymi urzędami administracji państwowej, w tym także DDDII, dotycząca przyjęć do klasztoru. Spotykamy tam informację, że o. Aleksy Łuczaj odszedł z klasztoru do pracy w diecezji. Spośród kandydatów, którym pozwolono wstąpić wymienia się: Kacpra Zaniewskiego, Jana Zienkowskiego, Michała Dudzińskiego, Stanisława Paszkiewicza.

Następne dokumenty mówią o przyjęciu nowych kandydatów, w tym kapłanów. Chociaż w latach 1912 - 1914 władze rosyjskie wydawały coraz więcej pozwoleń na przyjęcie do klasztoru, to jednak niektórych kandydatów należało usunąć. Jednak na usunięcie niegodnego zakonnika, podobnie, jak na przyjęcie kandydata, zgodę musiał wydać również minister spraw wewnętrznych ${ }^{69}$.

Zespół Wydziału Administracyjnego posiada też teczki dokumentów, dotyczących zapisów ofiar składanych na Msze św. na Jasnej Górze (np. teczka 9004).

Władze zbudowały zbiurokratyzowany system utrzymania klasztorów, aby kontrolować ich działalność. Wysokość wypłaty, należna na utrzymanie zakonnika, była ustalona przez rosyjskie władze centralne, lecz jej wyegzekwowanie przez klasztor nie było sprawą prostą. Każdą wypłatę musiała poprzedzać „,wielopiętrowa" korespondencja miedzy różnymi instytucjami państwowymi, które kontrolowały, czy faktyczny stan osobowy klasztoru odpowiada zgłoszonej wcześniej liście. Tego rodzaju dokumenty nie dają wglądu w życie duchowe klasztoru, lecz pozwalają zweryfikować niektóre daty czy też fakty, związane z tym życiem.

${ }^{67}$ Wszyscy trzej zostali osądzeni w Piotrkowie w 1912 r.

${ }^{68}$ Por. powyżej: Omówienie dokumentów DDDII w RGIA.

${ }^{69}$ APŁ, Wydział Administracyjny rządu gubernatora piotrkowskiego, Syg. 13307 (1912 r.), 13372 (1913 r.) - O peremenah v r.-k. monastyriah. 
Dają też możliwość zapoznania się z faktycznymi listami paulinów na Jasnej Górze, kapucynów w Nowym Mieście i dominikanek w Przyrowie.

Podsumowując wyniki kwerendy w APŁ, dotyczącej Jasnej Góry, można powiedzieć, że znajdują się tam dość duże zasoby dokumentów z okresu carskiego w języku rosyjskim. Dokumenty, dotyczące Jasnej Góry są rozproszone po różnych zespołach. Pewne wskazówki dla ich poszukiwań znajdujemy na stronach internetowych archiwum. Doświadczenie z tej kwerendy pozwala na ostrożne przypuszczenie, dotyczące podobnych poszukiwań w innych państwowych archiwach polskich. Prawdopodobnie nie znajdziemy w nich żadnych istotnych dokumentów, dotyczących Jasnej Góry na początku XX w.

Archiwum Główne Akt Dawnych w Warszawie posiada, co prawda, niektóre archiwalia, pochodzące $\mathrm{z}$ Kancelarii warszawskiego generał-gubernatora i innych urzędów. Wątpliwe, aby tam znalazła się jakaś dokumentacja, dotycząca Jasnej Góry. Nie należy też spodziewać się tego w zespołach, zawierających materiały wypracowane w kancelariach policyjnych. Badane przeze mnie teczki w APŁ, wypracowane w kancelariach policyjnych czy żandarmerii, dotyczyły przeważnie śledzenia działalności politycznej, zwłaszcza w partiach. Śledzenie „politycznej” działalności księży i zakonników było jedynie niewielką częścią tych trosk, które zostały włożone na siły policyjne.

Sprawy Kościoła katolickiego poprzez kancelarie administracyjne i policyjne powiatów, guberni, generał-gubernatora warszawskiego były wysyłane do petersburskiego Departamentu Spraw Duchownych Wyznań Obcych w Petersburgu i tam były interpretowane i rozstrzygane. Departament ten pełnił rolę policyjną w stosunku m. in. do Kościoła katolickiego. Wcześniejsza prezentacja zasobów RGIA świadczy o tym, że działania miejscowych administracji i policji wobec klasztorów, były zawsze uzgadniane z Departamentem Spraw Duchownych Wyznań Obcych.

\section{Zakończenie}

Omówione dokumenty świadczą o wielkim zbiurokratyzowaniu państwa rosyjskiego, które musiało utrzymywać wielopiętrową administrację, kontrolującą wszelkie przejawy życia obywateli, w tym również religijnego. Klasztor jasnogórski, ograniczony w swoim posłannictwie do minimum przez surowość represyjnego prawa, angażował znaczne siły państwa. Państwo brało na siebie funkcję sprawiedliwego podziału ofiar składanych przez katolików, uzależniając od woli urzędników sytuację materialną każdej osoby duchownej.

Całe represyjne prawodawstwo rosyjskie w stosunku do katolików i faktyczne wymarcie prawie wszystkich katolickich klasztorów świadczy o tym, że zamknięcie klasztoru jasnogórskiego było jedynie kwestią czasu i taktyki. Jasna Góra wraz z cudownym obrazem Matki Bożej - symbol swobody narodu polskiego, pomimo nieustannego zagrożenia - przetrwała jednak dzięki stałej obecności wytrwałych pielgrzymów. 
Biskupi katoliccy w Rosji carskiej byli całkowicie uzależnieni od administracji państwowej, dlatego nie należy spodziewać się, że w archiwach diecezjalnych znajdziemy jakieś sekretne dane, dotyczących Jasnej Góry. Warto byłoby jednak zbadać zasoby Archiwum Watykańskiego pod kątem ocen i charakterystyk Jasnej Góry, jakie docierały z Rosji do Rzymu.

\title{
РУССКИЕ ДОКУМЕНТЫ НАЧАЛА ХХ В. ОТНОСЯЩЕЕСЯ К ЯСНОЙ ГОРЕ
}

\begin{abstract}
Резюме
Город Ченстохов находился до I мировой войны в пределах Российской Империи. Это обусловило специфическую историю Ясной Горы. Автор, принимая во внимание состояние прежних исследований, предпринял попытку изучения российских архивных документов начала XX в., касающихся Ясногорского монастыря. Они сохранились в Российском государственном историческом архиве в Санкт-Петербурге и в Государственном архиве в г. Лодзь. Первые находятся в фонде Департамента духовных дел иностранных исповеданий Министерства внутренних дел, который контролировал неправославные вероисповедания, вторые — в фондах канцелярии и правительства Петроковского губернатора. Другие российские и польские архивы содержат лишь немногие документы, связанные с Ясной Горой. Документы подтверждают, что почти все решения, даже по незначительным вопросам, касающиеся монастыря, принимались российскими центральными властями в Санкт-Петербурге. Потом «спускались» по ступеням бюрократической лестницы, из Министерства внутренних дел, через Департамент духовых дел, в канцелярии Варшавского генерал-губернатора, Петроковского губернатора, начальника Ченстоховского уезда. Сходным был путь полицейских распоряжений. Большая часть проанализированных бумаг - входящая переписка и копии исходящих документов. Их ценность различна. Среди них есть как оригиналы, так и черновики высланных писем. Документы говорят об особом внимании российских властей к католической монашеской жизни, о стремлении к ее ограничению, а на самом деле к ликвидации. Сохранение паулинского монастыря в Ченстохове, несмотря на внешние репрессии и внутренние проблемы, свидетельствует об том, что он находился под особой Божьей защитой. Ясна Гора оставалась для лишенного независимости польского народа символом свободы и укрепляла веру и единство поляков. В то же время толпы паломников со всего разделенного границами края становились самой лучшей защитой монастыря от его ликвидации.
\end{abstract}

